\title{
Landet blir til - Norges geologi
}

Anmeldt af geologerne Jan Kresten Nielsen og Jesper Kresten Nielsen, Norge

Bogen Landet blir til - Norges geologi blev udgivet kort tid før jul sidste år og lanceret på en konference i det Norske Videnskapsakademi i Oslo. På initiativ fra Norsk Geologisk Forening er denne bog om Norges geologiske historie blevet til. Udover alle forventninger er bogen allerede blevet en stor succes i Norge - med over 2.100 forudbestillinger fra sponsorer, medlemmer og andre interesserede. Første oplag på 7.000 eksemplarer er blevet solgt på under 2 måneder. Den vil utvivlsomt få mange flere læsere. Andet oplag er netop trykt.

\section{En milepæl}

Det umiddelbare indtryk af bogen er det bedst mulige. Over 30 af Norges mest kendte geologer fra universiteter, forvaltning og industrien har skrevet de 17 kapitler, under kyndig ledelse af redaktionen. Deres bog er på et populært videnskabeligt plan og kan læses uden særlige forudsætninger. Dog forekommer der fagudtryk spredt i teksten. Disse er forklaret i ordlisten bagest i bogen. Med omfattende farverig illustrering og geologisk kort (målestok 1:2.000.000) er den-

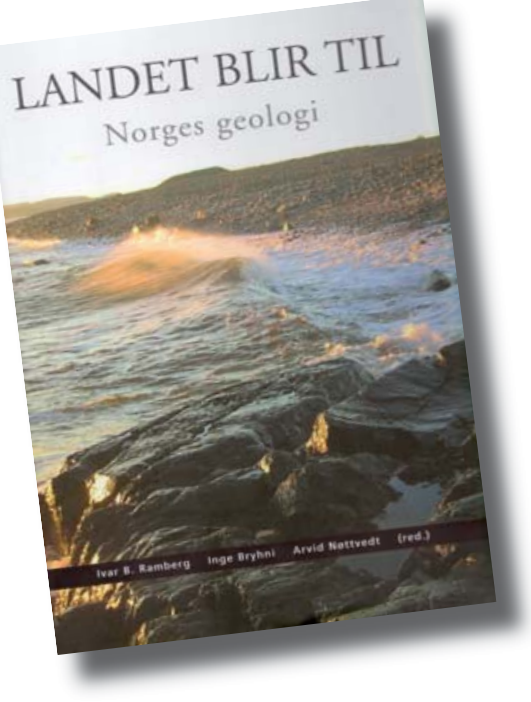

Verdens tredje største eksportør af olie og gas. Det er derfor naturligt at Norge har tradition for et stærkt geofagligt miljø, også inden for fjeldskred, malmudvinding og konstruktion af vej- og vandkraftanlæg. Bogens målgruppe er dog ikke kun uddannede geologer og geofysikere. Grundet bogens overskuelige opbygning og letlæselige fremstilling af emnet er den en geologisk skattekiste for alle interesserede. Bogens tykkelse på 4,5 cm og norske tekst bør ikke afskrække potentielle læsere. Mange af de geologiske principper omtalt i bogen vil kunne genkendes i den danske natur.

\section{En dansk pendant}

Et tilsvarende gedigent værk er bogen Geologien, der blev udgivet i 2006 som bind 2 i serien Naturen i Danmark. De læsere, som måtte have set denne danske pendant til Landet blir til - Norges geologi, kan have høje forventninger. Disse vil blive indfriet

ne velskrevne bog en milepæl; beskrivende den geologiske udvikling af Norge lige fra Jordens urtid til nu. Bogen er en opdateret afløser for forgængerne Geology of Norway (O. Holtedahl, red., 1960) og Norges geologi (C. Oftedahl, 1981, 2.udg.).

\section{Et værk der kan læses af alle}

Norge er et land med store naturressourcer i undergrunden, som er udvundet i generationer til norsk såvel som udenlandsk industri. Omkring 40 år siden begyndte søgningen efter olie og gas til havs, og i dag er Norge med Landet blir til - Norges geologi. Bogen repræsenterer et omfattende arbejde og kan meget vel give inspiration til kommende rejser i Norge.

Ramberg, I.B., Bryhni, I. og Nøttvedt, A. (red.) 2006. Norsk Geologisk Forening (NGF), Trondheim. 608 sider. ISBN 8292394-31-1. Bogen kan bestilles direkte fra NGF. Tlf.: +47 73904091. E-mail: bok@ geologi.no. Pris: 395,- NOK for geo-interesserede som ikke er medlemmer af NGF; 350,- NOK for NGF medlemmer. 